\title{
Glycemic Index of Sweet Potato as Affected by Cooking Methods
}

\author{
Jonathan C. Allen, ${ }^{*,}$, Alexis D. Corbitt ${ }^{1}$, Katherine P. Maloney ${ }^{1}$, Masood S. Butt ${ }^{2}$ and \\ Van-Den Truong ${ }^{1,3}$
}

\author{
${ }^{I}$ Department of Food, Bioprocessing, and Nutrition Sciences,North Carolina State University, Raleigh NC 27695-7624, USA \\ ${ }^{2}$ National Institute of Food Science and Technology, University of Agriculture, Faisalabad, Pakistan \\ ${ }^{3}$ USDA-ARS Food Science Research Unit, North Carolina State University, Raleigh NC 27695-7624, USA
}

\begin{abstract}
Understanding the effect of cooking on glucose availability will aid in the recommendation for including sweet potatoes as a regular component in American diets. Heating breaks down starch granules to allow amylopectin and amylose to be more readily digested by pancreatic amylase, which theoretically should increase the glycemic index of sweet potato. Twelve volunteers consumed $25 \mathrm{~g}$ of available carbohydrate from Beauregard sweet potato skin and flesh separately that were subjected to conventional cooking methods: baking at $163{ }^{\circ} \mathrm{C}$ for 1 hour; microwaving for five minutes in a 1000 watt microwave; dehydrating at $60^{\circ} \mathrm{C}$ for 16 hours; and steaming at $100^{\circ} \mathrm{C}$ for 45 minutes. Available carbohydrate was determined by difference from proximate analysis of protein, lipid, total dietary fiber, moisture, and ash. Fasted participants measured blood glucose levels at $0,30,60,90$, and 120 minutes after consuming $25 \mathrm{~g}$ of carbohydrate from test foods or glucose. Glycemic indices calculated from these methods for steamed, baked and microwaved sweet potato flesh were $63 \pm 3.6,64 \pm 4.3$ and $66 \pm 5.7$, respectively, indicative of a moderate glycemic index food. However, dehydrated and raw sweet potato flesh had a low glycemic index (41 \pm 4.0 and $32 \pm 3.0$, respectively). Steamed skin, baked skin, and dehydrated flesh did not have a statistically different glycemic index $(P>0.05)$ from that of raw sweet potatoes. A second experiment confirmed the low glycemic index of raw sweet potato, especially the skin, and showed that a commercial extract of the sweet potato cortex, Caiapo, tended to lower the glycemic index of white potato to a level that was not different from the raw sweet potato peel. The physiological mechanism for the lower glycemic index was not due to a greater release or a greater clearance of insulin during the glycemic response. Depending on cooking methods, "Beauregard" sweet potato flesh and skin may be considered low and medium glycemic index foods, which may prove beneficial for diabetic or insulin-resistant consumers.
\end{abstract}

Keywords: Sweet potato, glycemic index, cooking, insulin.

\section{INTRODUCTION}

Glycemic index (GI), which is a ranking of carbohydratecontaining foods according to their immediate effects on blood sugar levels, has significant public interest and scrutiny [1]. Pure glucose is usually used as the standard to which other foods are compared and is given the glycemic index of 100. Although all dietary carbohydrates provide the same amount of energy, they are not all handled with equal efficiency by the body [2]. The glucose absorbed from any given food is affected by physiological and nutritional factors, which include the digestibility of the starch, interactions of starch with proteins, amounts and kinds of fat, sugar and fiber in the presence of constituents, and the level and type of food processing [3-5]. Changes in the physiological state of the food, from green to ripe, increases its glycemic index [3]. Several other factors influencing glycemic index are the source and class of carbohydrate, resistant starches, amylose and amylopectin levels, fiber content, and cooking.

*Address correspondence to this author at the Department of Food, Bioprocessing and Nutrition Sciences, North Carolina State University, Raleigh, NC 27695-7624, USA; Tel: 919-513-2257; E-mail: jon_allen@ncsu.edu
The starch in raw food is stored in compact granules that are difficult to digest [6]. The cooking process causes hydrogen-bonding sites involved in intermolecular bonds of starch molecules to engage more water, releasing individual molecules [7]. Gelatinization occurs when starch molecules enter the aqueous solution followed by total disruption of the granules in a sequential process [8]. Starch is gelatinized at $60-90^{\circ} \mathrm{C}$ and becomes susceptible to hydrolysis by alpha and beta amylase. Incomplete cooking processes followed by cooling results in starch becoming resistant to digestion [9] leading to slow digestion and lower glycemic response.

Starch hydrolysis varies from quite rapid to very slow. Small intestinal starch digestion may be so retarded that starch can escape into the large bowel without being digested [10]. This fraction is termed resistant starch, which is likely formed during cooling after the starch has been gelatinized during cooking with heat and excess water. Disruption of the crystalline structure takes place at temperatures of 60 to 70 ${ }^{\circ} \mathrm{C}$ [11]. Above $90{ }^{\circ} \mathrm{C}$, fragments of amylopectin and amylose are suspended in water due to the significant loss of granular structure [12]. Granules high in amylose swell more slowly than those rich in amylopectin due to amylopectin's increased branching.

Cooked food is almost always stored for variable lengths of time under moderate or low temperatures before con- 
sumption. Amylose and amylopectin molecules can associate to form a gel [13]. The exact nature of the gel depends on amylose:amylopectin ratio, amount of water, and time and temperature of storage [14]. The gel network is created by glucan chains that retrograde (recrystallize) in a helical structure [11]. It may take hours or days to form this gel. Retrogradation may also be increased by replicated heated and cooling [15]. The change in structure of starches during heating and cooling has a significant influence on starch digestibility in the gastrointestinal tract. Some evidence from intubated humans indicates that free glucose may pass to the colon from traces found in the terminal ileum [16]. This too is termed resistant starch since it escapes digestion. Englyst, et al., [17] classified resistant starches according to the cause that allows them to pass to the large bowel: chemically resistant starch (i.e. enzyme resistant starch) and physiologically resistant starch (i.e. starch that passes undegraded through the small intestine and into the large bowel). Raw starches are highly resistant to enzymatic hydrolysis compared with gelatinized starches [14].

Soh and Brand-Miller [18] found no significant difference in GI of potatoes prepared by boiling, oven-baking, microwaving, or mashing. Conversely, Crimi, et al., [19] found that baked potatoes produced a significantly lower incremental glycemic response compared with boiled potatoes. Wolever, et al., [20] also found no differences in baking, boiling, and canned potatoes, but found that mashing significantly increased the glycemic response (by 15-20\%). The variability noted in potatoes, although of a different species than sweet potatoes, leads to questions surrounding the effect of cooking methods on glycemic index with sweet potatoes.

Baked sweet potato elicited a high GI of 94 when studied with 14 West Indian carbohydrate rich foods [3]. This study found boiled sweet potatoes to have a low GI of $46 \pm 5$. Likewise, the roasted tubers were all high (82 for sweet yam). Blood glucose response curves for low $(\leq 55)$, intermediate $(56-69)$, and high $(\geq 70)$ GI foods were similar to the relationship shown in the response curves of boiled, roasted, and fried sweet potato. These results suggest the different processing methods used (boiling, roasting, baking, or frying) may influence the GI of sweet potatoes.

Extrusion cooking, explosion puffing, and instantization appear to make the starch of rice, potato, and corn products more readily digested [21]. Hydration of granules (gelatinization) and disruption of organized granule structure increase the availability of starch to amylase digestion and are more likely to occur in processing factory cooking conditions when higher temperatures and pressures are utilized. The more processed a food is, the higher the glycemic response it will produce [22]. Conventionally cooked starches may be recommended for diabetics to achieve glycemic indices lower than those processed in factories.

Boiling may cause leaching of glucose monomers from amylose-amylopectin degradation. Loss of the readily digestible sugars due to leaching did not impact the amount of carbohydrate used to calculate the GI of boiled or steamed foods [3]. Using wet heat to cook a potato can increase resistant starches. Baking foods uses dry heat, causing loss of water and concentrating free sugars. The degradation of starches further increases the sugar content and glycemic index. Cutting sweet potatoes into strips and cooking rapidly retained significant amounts of starch, whereas the cooking of whole roots allowed more complete conversion of starch into sugars and dextrins [23]. Conversely, sugar concentrations were similar in roots cooked in microwave and convection ovens [24].

The recrystallization of dispersed starches results in stronger hydrogen bonds [25]. The cook-cool-re-warming of the potatoes affected about $7 \%$ of the starch and allowed it to escape digestion in the small intestine compared to about 3\% in freshly cooked potato [26]. Earlier studies on potatoes in vitro showed cooling, freezing, or drying produces starches partially resistant to $\alpha$-amylase. Digestibility of starch made resistant to $\alpha$-amylase by cooling improves on reheating. The increased resistance to amylase on cooling appeared to relate to changes in crystalline structure of starch rather than overall physical form [26]. The resistant starches do significantly affect the glycemic index.

Protein within sweet potato also exhibited high amylase activity with an average of 480 units/mg protein and a range of 274-758 units/mg protein [27]. After heating the extract for 10 minutes at $80^{\circ} \mathrm{C}$ to destroy native amylase activity, amylase inhibitory activity was assayed via the dinitrosalycylic acid method. No amylase inhibitors were found in the sweetpotato extract. Rekha, et al., [28] found that native amylase activity remained after heating for 10 minutes at $80^{\circ} \mathrm{C}$ and thus used trichloroacetic acid to selectively precipitate the amylases before assaying the extract for amylase inhibitory activity via the iodine binding method. Of the 100 cultivars studied, amylase inhibitors were found in 79 .

Cultivar also can play a significant role in the stability of the amylase inhibitors [29]. Boiling sweetpotato pieces in water for 30 minutes resulted in residual amylase inhibitor activities of $29.3 \pm 1.1 \%$ (cultivar RS III), $29.1 \pm 1.1 \%$ (cultivar S 62), $44.6 \pm 1.9 \%$ (cultivar S 56-2), and $58.9 \pm 0.7 \%$ (cultivar S 1195). Microwave baking resulted in complete amylase inhibitor inactivation in the S 62 cultivar after 120 seconds and the S 1195 cultivar after 180 seconds. Residual amylase inhibitor activities of $29.1 \pm 1.1 \%$ and $19.2 \pm 0.6 \%$ remained after 180 seconds in the cultivars RS III and S 562 , respectively. Grating or blending, oven drying at $70^{\circ} \mathrm{C}$ for 24 hours, and then powdering to obtain flour resulted in complete inactivation of amylase inhibitors in all cultivars tested [29].

Sweetpotatoes contain multiple proteins that exhibit trypsin inhibitor activity. Trypsin inhibitors have been identified with molecular weights of 23 and $24 \mathrm{kDa}$ [30, 31], molecular weights of 73,38 , and $22 \mathrm{kDa}$ [32], and 10 different trypsin inhibitors with the most active inhibitors having molecular weights of 12,10 , and $9.3 \mathrm{kDa}$ [33]. Trypsin inhibitors had no effect on chymotrypsin and pepsin activity [30]. Processing of sweetpotatoes can greatly affect the activity of trypsin inhibitors. Boiling sweetpotatoes for 40 minutes resulted in complete inactivation of trypsin inhibitors [33]. Microwave baking was the most effective method for inactivating trypsin inhibitors in sweetpotatoes followed by boiling and then oven-drying [34]. Microwave baking for 180 seconds resulted in complete inactivation of trypsin inhibitors while boiling for 30 minutes resulted in $17-31 \%$ residual activity. Trypsin inhibitors in oven-dried sweetpotato chips were relatively stable for 2 hours at $70^{\circ} \mathrm{C}$, with $80-90 \%$ residual activ- 
ity. After 2 hours, however, inactivation progressed at a more rapid rate, with less than $20 \%$ activity remaining after 24 hours. Higher temperatures also led to more rapid inactivation, with inactivation complete after 4 hours at $100^{\circ} \mathrm{C}$. Minor variations in thermostability were seen for different cultivars. Moist heat treatment provided better inactivation of trypsin inhibitors than dry heat treatment [35]. Dry heat treatment at 60,80 , and $100^{\circ} \mathrm{C}$ for 15 minutes resulted in average residual activities of 92,84 , and $71 \%$, respectively, where as moist heat treatment at 60,80 , and $100^{\circ} \mathrm{C}$ for 15 minutes resulted in average residual activities of 71,26 , and $5 \%$, respectively. Similarly to Kiran and others [34], Zhang and Corke [35] found that the trypsin inhibitors of some cultivars were more heat resistant than others. Protease inhibitors that are not degraded could impact the degradation of amylase and thereby affect starch digestion and glycemic index.

The glycemic index of sweet potato reported by various researchers ranges from 44 to 94 [36]. These studies vary in cultivar, growing location, and preparation methods. Although generally considered sweet by definition, there is a large range of perceived sweetness, depending on sugar components and starch conversion during cooking of sweet potatoes [37]. Collins and Walter [23] estimated available sugar values between $30-35 \%$ on a dry-weight basis. Raw sweet potato tissue contains sucrose, glucose, and fructose. The principal change in sugar composition with cooking is the production of maltose from hydrolyzed starch. Much of the starch is converted into dextrins and maltose by alpha amylase and beta-amylase; however the degree of starch conversion can differ across cultivars [38].

We do not understand all the components associated with the low glycemic index in raw sweet potatoes [39]. Proteins, fiber, or starch are components that could be attributed to the low glycemic index of sweet potatoes. Ludvik, et al., [40] reported beneficial effects of Caiapo, an extract of the whiteskinned sweet potato (Ipomoea batatas L.), on fasting plasma glucose, total cholesterol, and low-density lipoprotein (LDL) cholesterol in type 2 diabetic patients. This sweet potato variety has been cultivated in the Kagawa Prefecture in Japan and the extract of the skin of the root is used for the treatment of type 2 diabetes in Japan. The isolated antidiabetic component of Caiapo is an acidic glycoprotein that is similar to the proteins found in Beauregard and White Star sweet potatoes (Ipomeabatatas L.) [40, 41]. However, sweet potatoes are rarely consumed raw in most countries due to the starchy flavor. Thus, cooking could affect sweet potato glycemic index by denaturing the Caiapo glycoprotein. In developing countries, the consumption of sweet potato appears to be inversely proportional to income level, and they are typically viewed as a food to be consumed only for survival [42].

Theoretically, an increase in simple sugars should cause higher glycemic indices due to improved sugar availability. Other compounds, such as fiber, can confound this effect by maintaining low glycemic index values [43, 44]. Consumption of dietary fiber, particularly viscous fiber, may alter the digestion and absorption of carbohydrates whereas lipids delay gastric emptying to the small intestine and retard interaction with digestive enzymes [10]. Nishimune, et al., [43] further explained the effect of total dietary fiber on polysac- charide absorption through five mechanisms. Fiber delays the digestion of starch in the stomach; secondly, fiber will delay the transition time of stomach contents to the duodenum; thirdly, fiber will delay the diffusion of different saccharides in the duodenum, and fourthly, fiber will delay the hydrolysis of polysaccharaides in the upper parts of the duodenum. Finally, fiber will lower the rate of absorption of monosaccharides through the microvilli of the epithelial cells in the jejunum and upper ileum. Dietary fiber, with increasing concentration, may act as a competitor for sugar uptake through a membrane because fiber may compete with sugars released during cooking for the same binding site [41].

This study aimed to investigate the change in glycemic index after cooking sweet potatoes under conventional domestic methods. Sweet potatoes are commonly cooked using various methods. Baked sweet potatoes are popular in the Americas. The North Carolina Sweet Potato Commission [45] recommends baking at a temperature of $350^{\circ} \mathrm{F}\left(177^{\circ} \mathrm{C}\right)$ for forty minutes. Sweet potatoes are also boiled and steamed in many countries and cultures. Dehydrated sweet potatoes are consumed as chips for snacks. The objective of this study was, first, to determine the effect of cooking by different methods on the glycemic index of sweet potato skin and flesh, and, secondly, to investigate the physiological impact and causes of low glycemic effect of raw sweet potato and its components.

\section{MATERIALS \& METHODS}

\section{Reagents}

Hydrochloric acid $(\mathrm{HCl})$ was purchased from Fisher Scientific (Fair Lawn, NJ) to digest dehydrated samples. Sodium sulfate (anhydrous) was used to dry lipid samples dissolved in n-hexane, also purchased from Fisher Scientific. Heat stable $\alpha$-amylase, protease, and amyloglucosidase were provided in a Megazyme total dietary fiber assay procedure kit AOAC 991.43 (Bray, Co. Wicklow, Ireland). MES/TRIS buffer (2N-morpholino ethanesulfonic acid and tris(hydroxymethyl) aminomethane) $(0.05 \mathrm{M})$ at $\mathrm{pH} 8.2 \mathrm{ad}-$ justed with 6N HCL was prepared using reagents from Sigma- Aldrich (St. Louis, MO). Celite, acid-washed, prewashed from World Minerals was also used in the total dietary fiber assay. Ethanol (95\%), 78\% ethanol (AAPER Alcohol, Shelbyville, Kentucky), and acetone (Fisher Scientific, St. Louis, MO) used for washing of total dietary fiber samples were reagent grade. Glucose oxidase/ peroxidase and odianisidine reagents were provided in the Glucose (GO) assay kit by SIGMA- Aldrich (GAGO-20) (St. Louis, MO). Cpeptide (10-11136-01) and insulin (10-1113-01) ELISA assay kits were manufactured by Mercodia (Sweden, ALPCO Diagnostics, Windham, NH). Caiapo was obtained from Fuji-Sangyo Company (Japan).

\section{Instrumentation}

Sweet potato roots were skinned using a household potato peeler. Conventional ovens were used for baking. Temperature was checked by an oven thermometer. Sweet potato samples were dehydrated in a Precision Scientific economy oven (Chicago, IL) that operated by mechanical convection. A 10-cup household steamer was used to steam sweet potato slices. Sweet potato samples were microwaved at full power (750 watts) in General Electric 'Hotpoint' ${ }^{\circledR}$ (Fairfield, CT) microwave oven in food grade areas of the lab. 
A Cuisinart ${ }^{\circledR}$ 14-cup food processor blended samples after cooking for freeze drying. Cooked sweet potato samples were prepared for proximate analysis using a vacuum bottle type 4.5-L benchtop freeze dryer (Labconco, Kansas City, Missouri) to ensure complete dehydration of pureed sweet potato samples. Coffee grinders were used to create a sweet potato powder suitable for analysis of macronutrients.

Digestion conditions were simulated in hot water baths made by Precision Scientific. A rotary evaporator was utilized to remove n-hexane solvent from solution in lipid extraction procedures. Fritted crucibles (Pyrex $50 \mathrm{~mL}$ ASTM 40-60 C) were used for filtering samples in total dietary fiber separation extraction methods. Samples were ashed at 525 ${ }^{\circ} \mathrm{C}$ in a muffle furnace (Barnstead/ Thermolyne, Dubuque, IA) and cooled in desicators. Therasense ${ }^{\circledR}$ Freestyle glucometers (Abbott Diabetes Care, Inc., Alameda, CA) were used to monitor changes in blood glucose levels of volunteers. The accuracy of the glucometers was confirmed by comparing readings from approximately 20 subjects with analysis of serum glucose collected from the same subjects at the same time using a glucose oxidase microtiter plate method (GAGO-20, Sigma, St. Louis, MO).

\section{Cooking Methods}

Sweet potatoes were grown at the NCSU Research Farm in Clinton, North Carolina, cured at $30{ }^{\circ} \mathrm{C}, 85 \%$ relative humidity, and held in a temperature controlled cooler $\left(13{ }^{\circ} \mathrm{C}\right.$, $85 \%$ relative humidity) in NC State University's Horticulture Department after harvest. Samples were retrieved from storage coolers, washed and allowed to dry at room temperature $\left(22^{\circ} \mathrm{C}\right)$ for 10 minutes. Inedible portions were removed and not used in cooking. Samples were then skinned for flesh and skin fractions to be separated and weighed to 25 -g available carbohydrate quantities determined from proximate analysis. The conventional cooking methods investigated in this study were baking, dehydrating, steaming, and microwaving. These cooking methods were intended to be representative of common sweet potato preparations.

Raw sweet potato samples were sliced and baked to 163 ${ }^{\circ} \mathrm{C}\left(325{ }^{\circ} \mathrm{F}\right)$ for one hour in sealed aluminium foil packets. Peeled raw sweet potatoes were thinly sliced using a Cuisinart ${ }^{\circledR}$ food processor with a $4 \mathrm{~mm}$ blade. The slices were then placed on baking sheets in a dehydrator at $60{ }^{\circ} \mathrm{C}$ for 16 hours. Other slices were placed in a home steamer for 45 minutes and in a domestic microwave at 750 watts for 5 minutes.

If sweet potato roots are cut into strips and cooked rapidly, significant amounts of starch remain, whereas the cooking of whole roots allows a more complete conversion of starch into dextrins and sugars [38]. Since processing of sweet potato into pieces before cooking is standard method used in both household and industrial sweet potato preparation [45], it was used in this study.

After cooking, samples were placed in a refrigerator (4-6 ${ }^{\circ} \mathrm{C}$ ) for a maximum of one week until needed and then warmed for one minute in a microwave oven for volunteer consumption. Thereafter, any unused samples were discarded.

\section{Proximate Analysis}

Carbohydrate content was quantified in raw, baked, steamed, and dehydrated sweet potatoes. Analysis was conducted on duplicate samples after cooking to observe the possible change in macronutrient levels through leaching or other manner. The proximate compositions of total dietary fiber, ash, lipid, and moisture contents for the different cooking methods of sweet potatoes were determined using a standard method [46] and available carbohydrate content was calculated by difference $[6,47]$.

\section{Total Dietary Fiber}

The AOAC 991.43 Megazyme kit method required samples to be cooked at $100{ }^{\circ} \mathrm{C}$ with heat stable alpha amylase to give gelatinization, hydrolysis and depolymerization of starch. Incubation at $60^{\circ} \mathrm{C}$ with protease followed to solubilize and depolymerise proteins and amyloglucosidase to hydrolyze starch fragments to glucose. Treatment with ethanol precipitated the soluble fiber and removed depolymerized protein and glucose from starch. The residue was then filtered and washed with 78\% ethanol, 95\% ethanol, and acetone. One duplicate was analyzed for protein and another for ash. Total dietary fiber was then calculated by difference from filtered and dried residues.

\section{Lipid}

Acid hydrolysis was used to release bound lipids, polar and non-polar, by dissociating lipid-starch and lipid-protein intermolecular forces. Samples were hydrolyzed with hydrochloric acid under heat. Extraction of lipids using hexane retained lipid in the organic solvent. The organic layer was filtered through sodium sulfate and evaporated at $40^{\circ} \mathrm{C}$ under reduced pressure using a rotary evaporator. The resulting weight was subtracted revealing the amount of lipid present.

\section{Moisture}

Sweet potatoes were placed in a moisture determination dehydrator. The sample was automatically weighed, dehydrated to a constant weight, and the percentage of moisture was then calculated and displayed.

\section{Protein}

The NC State University Analytical Spectroscopy Services Laboratory determined dry matter nitrogen levels as a part of the analysis using a C-H-N $2400 \mathrm{CO}_{2}$ Elemental Analyzer (Perkin Elmer, Norwalk, CT). The amount of protein was determined from $\mathrm{N}$ content x $6.25(16 \% \mathrm{~N}$ in sweet potato protein).

\section{Ash}

Ash was measured by placing samples in a muffle furnace for five hours at $525^{\circ} \mathrm{C}$. The high constant temperature destroyed all compounds other than minerals found in the sweet potato. An analytical error in some of the cooked samples required that we use the ash content of the raw material in the calculation of carbohydrate content.

\section{Human Subject Panel: Experiment 1, Cooking Methods}

The experimental procedure was approved by the NCSU Institutional Review Board. All subjects signed informed consent documents. Once $25 \mathrm{~g}$ of carbohydrate was deter- 
mined by proximate analysis of other macronutrients and components, 12 volunteers were recruited to participate in the feeding trial. All volunteers were healthy participants, free of chronic carbohydrate metabolism disease, who consented to the approved protocol of the research. The study required two months for completion. Participants were financially compensated for each completed day of the panel. Questionnaires were provided to the volunteers for age, gender, medical history, and normal daily carbohydrate consumption information. Anthropometric data measured were for weight and height for subjects at the commencement of the study. Body mass index (BMI) was calculated from the measured data.

Samples were warmed for one minute in a microwave oven on the day they were needed for each volunteer [3]. Three hundred $\mu \mathrm{L}$ of blood was collected on the first day of the study to be analyzed for fasting insulin levels to remove participants with hyperinsulemia. Volunteers began between 7 a.m. and 9 a.m. after fasting for at least 7 hours. A fasting blood glucose level was taken using Therasense ${ }^{\circledR}$ Freestyle glucometers (Alameda, CA) and followed by participants consuming their samples in 15 to 20 minutes. Previous research [48] showed no difference between venous and capillary blood samples using continuous glucose monitoring systems for determining the blood glucose response to food. The time when participants completed each sample was recorded and blood glucose levels were taken in thirty-minute increments thereafter, stopping at two hours.

\section{Human Subject Panel: Experiment 2, Raw Sweet Potato and Potato}

Beauregard sweet potato roots grown in Clinton, North Carolina were washed, skinned, and prepared by grating using a Cuisinart ${ }^{\circledR}$ food processor (East Windsor, NJ). All 200 -g portions of sweet potato (skin, flesh, or whole) were weighed, placed in Ziplock bags, and stored in food grade freezers for a maximum of one week until needed for participants. White potatoes (Solanum tuberosum) were purchased at a local supermarket. The treatments consumed for this study were $\mathrm{T} 1=$ Glucose drink, $\mathrm{T} 2=$ whole sweet potato, $\mathrm{T} 3=$ sweet potato flesh, $\mathrm{T} 4=$ sweet potato skin, $\mathrm{T} 5=$ white potato, $\mathrm{T} 6=$ white potato plus Caiapo $(4 \mathrm{~g})$. All sweet potato samples were consumed raw, unexposed to any cooking heat. White potato samples were microwaved in the food grade lab for 3 minutes at 750 watts to reduce potential solanine toxicity. Frozen samples were thawed each morning for 1.5 hours at room temperature $\left(22{ }^{\circ} \mathrm{C}\right)$ before consumption. Approximately 4 grams of Caiapo was added to white potato and mixed prior to eating. Each treatment was consumed on two different days by each subject to determine glycemic index.

Volunteers arriving at the test site were asked to recall the last meal consumed prior to the required 8-hr fast. Fisher ${ }^{\circledR}$ HealthCare Brand (ArtaPlast AB, Fisher HealthCare, Houston, TX) self-retracting safety lancets were provided to prick the tips of their fingers for fasting glucose level determination by Therasense ${ }^{\circledR}$ Freestyle glucometers. Participants were then asked to consume 50-g of Fisherbrand Sun-Dex Glucose Tolerance Test Beverages (Houston, TX) to obtain the standard glycemic response against which sweet potato samples were measured. Blood glucose levels were subsequently measured by glucometer at times 30,60 , 90 , and 120 minutes after consuming the sample. An additional $400 \mu \mathrm{L}$ of blood were collected in BD Microtainer serum separator tubes, centrifuged ten minutes, and frozen for further analysis of C-peptide and insulin concentrations. Participants consumed each treatment twice over the course of a month and a half. Serum insulin and C-peptide concentrations from times 0,60 , and 120 minutes were measured from thawed blood samples using the Mercodia Insulin ELISA assay and Mercodia C-peptide ELISA.

\section{Glycemic Index Analysis}

Each subject consumed each food sample on two separate days for improved statistical accuracy. The incremental areas under the curve, excluding the area beneath the fasting level, were calculated by weighing geometrically [49]. Glucose responses were graphed for each individual using Microsoft Excel and printed on 8.5" x 11" acid-free paper. The area under the curve, not considering regions below the time zero baseline glucose concentration, was cut and weighed on Denver Instruments and Sartorius Analytical balances. The glycemic index was calculated by expressing the glucose response area for the test foods as a percentage of the mean response area of the reference food (glucose drink) taken by the same subjects $[20,49]$. The geometric weighing technique compared favorably with area-under-the-curve data obtained with a polar planimeter.

\section{Statistical Analysis}

A $t$ test (LSD) using SAS 9.1 compared glycemic index means for each treatment to calculate statistical differences [2]. A program considering the interaction of treatment (baking, steaming, and raw) and part (skin vs. flesh) was used to analyze their effect on the glycemic index, followed by Duncan's Multiple range test to determine differences between treatment means. In Experiment 2, the slopes of trend lines from $0-60$ minutes and $60-120$ minutes for insulin and C-peptide concentrations were graphed and analyzed by ANOVA. If there were significant main effects, Tukey's HSD procedure was used to identify any treatments with significantly different insulin or C-peptide release or clearance rates.

\section{RESULTS}

\section{Anthropometric and Demographic Description of Sub- jects}

Participants completed questionnaires regarding age, date of birth, weight, height, carbohydrate metabolism deficiencies, smoking habits, carbohydrate source, physical activity, and medical history. Twelve volunteers began and ended the study, seven female and five male. Volunteers were not screened for high or low carbohydrate intake or source. All were non-diabetic and considered normal for the purposes of the study. The average age was $32 \pm 12$ yr. Ages ranged from twenty-two to sixty-three. BMI was calculated from the weights and heights. The mean BMI among participants was $24.63 \pm 3.62 \mathrm{~kg} / \mathrm{m}^{2}$, which is considered a healthy BMI [50]. The average weight among volunteers was $73.1 \pm 12.2 \mathrm{~kg}$ $(161.14 \pm 26.87 \mathrm{lb})$ and height was $1.701 \pm .095 \mathrm{M}\left(5^{\prime} 7^{\prime \prime} \pm\right.$ 3.74 "). No participants reported that they currently smoked. 


\section{Proximate Composition of Sweet Potatoes}

Variability was noted in proximate analysis results. Calculations were on dry matter basis due to dehydration requirements for assay procedures. The various samples averaged $3.9 \pm 1.7 \%$ ash, $31 \pm 14 \%$ total dietary fiber, $1.0 \pm 0.7 \%$ fat and $7.6 \pm 0.9 \%$ protein (means \pm S.D.). Dry matter content ranged from $12.8 \%$ for the baked flesh to $75.3 \%$ for the dehydrated skin. The serving sizes providing $25 \mathrm{~g}$ of carbohydrate in each treatment were calculated to be $264 \mathrm{~g}$ of Raw Skin, $189 \mathrm{~g}$ of Raw Flesh, $445 \mathrm{~g}$ of Steamed Skin, $148 \mathrm{~g}$ of Steamed Flesh, $146 \mathrm{~g}$ of Baked Skin, $261 \mathrm{~g}$ of Baked Flesh, $64 \mathrm{~g}$ of Dehydrated Skin, and $53 \mathrm{~g}$ of Dehydrated Flesh. Lanza, et al., [51] found that sweet potatoes have an average dietary fiber content of $2.4 \mathrm{~g} / 100 \mathrm{~g}$ fresh weight using the neutral detergent fiber plus water soluble fraction and Southgate procedure for extracting the fiber. The value was an average taken from compiled literature sources. Our data show values on a dry weight basis that are substantially higher in fiber content (3.3 to $5.6 \%$ for flesh) than the average sweet potato in the earlier study [51], possibly because the Megazyme fiber assay could include resistant starch, or that it extracts non-fiber components and calculates fiber by difference, as opposed to a harsher fiber extraction method [52]. In Experiment 2, the proximate analyses determined the carbohydrate content (percent nitrogen-free extract, drymatter basis) to be $90.1,79.6$, and $95.4 \%$ for whole sweet potato, sweet potato skin, and whole white potato; the dry matter content was $17.57,18.61$ and $17.86 \%$, respectively.

\section{Blood Glucose Response to Cooking (Experiment 1)}

A fasting blood sample was collected before any food intake and additional blood samples were drawn and analyzed in 30-min increments after participants completed consuming samples. Fig. (1) shows the mean glucose response levels and standard errors. The glycemic response to each food preparation method was determined in all twelve subjects on two separate occasions, except that dehydrated skin was not consumed by all subjects due to severe gastrointesti- nal difficulty by three volunteers. Symptoms included cramping, nausea, vomiting, and constipation. These symptoms were reported to only last for a maximum of six hours. An analysis of interaction between cooking method (steamed, baked, raw) and part (skin vs. flesh) using a comparison of means revealed that glycemic index values for part were dependent on the method of cooking and vice versa $(\mathrm{P} \leq 0.001)$. Furthermore, there were significant differences in glycemic indices based on cooking method $(P \leq$ $0.001)$ and part $(P \leq 0.001)$. No significant differences $(P>0.05)$ were observed among subjects or between replications.

Table 1 shows the calculated glycemic index for each sample. Glucose was given the value of 100 . The Type III Sum of Squares analysis of subjects indicated no differences in glycemic indices calculated from subjects for each treatment $(P=0.573)$. Significant differences were observed by treatment $(P \leq 0.0001)$. A t-test on least squares (LSD) of glycemic index means determined that some samples had values significantly different from others. Microwavecooked flesh samples had a medium glycemic index of 66 followed by baked flesh (64), and steamed flesh (63). These values were statistically similar to one another. Dehydrated flesh had a glycemic index of 41, which was grouped with baked skin (32), raw flesh (28), and steamed skin (25). The final group consisted of baked (32), steamed (25), and raw skin (19) and raw flesh (28).

\section{Blood Glucose, Insulin and C-peptide Responses to Raw Sweet Potato Components and Controls (Experiment 2)}

A second glycemic response experiment was conducted to further investigate possible mechanisms for the low glycemic index of raw sweet potato. Fig. (2) shows the mean glycemic response for the treatments studied, compared to a standard control trial of $50 \mathrm{~g}$ of glucose drink. The sweetpotato treatments were also compared to a control dose of white potato (Solanum tuberosum) and white potato to which was added a 4-g portion of Caiapo. Using the methods de-

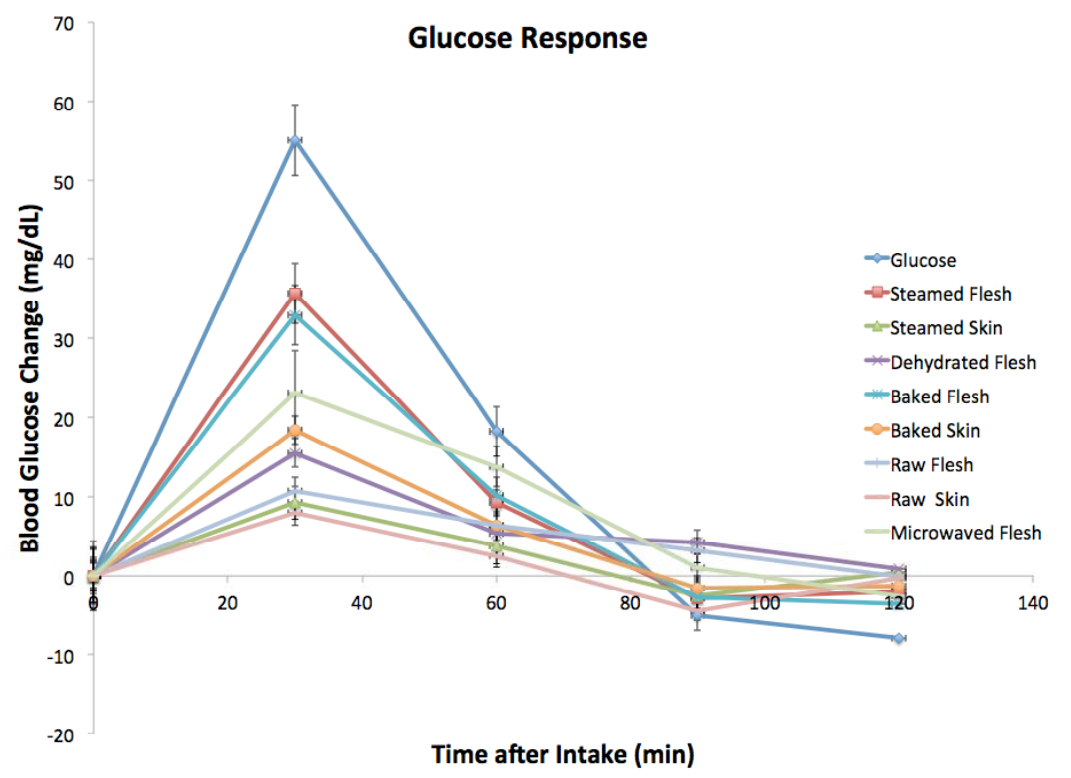

Fig. (1). Mean Glucose Response from Participants consuming cooked Beauregard Sweet Potato Samples containing 25 g of carbohydrate. Vertical bars are the standard error of duplicate analyses for 12 subjects. 
Table 1. Calculated Glycemic Indices of Cooked Beauregard Sweet Potato ${ }^{1}$

\begin{tabular}{|c|c|c|}
\hline Cooking Method & Flesh & Skin \\
\hline \hline Raw & $32 \pm 3.0^{\mathrm{B}, \mathrm{C}}$ & $19 \pm 3.6^{\mathrm{C}}$ \\
\hline Steamed & $63 \pm 3.6^{\mathrm{A}} \pm 3.0^{\mathrm{B}, \mathrm{C}}$ \\
\hline Baked & $64 \pm 4.3^{\mathrm{A}}$ & $34 \pm 2.3^{\mathrm{B}, \mathrm{C}}$ \\
\hline Microwaved & $66 \pm 5.7^{\mathrm{A}}$ & N.D. $^{2}$ \\
\hline Dehydrated & $41 \pm 4.0^{\mathrm{B}}$ & N.D \\
\hline
\end{tabular}

${ }^{1}$ Values are mean \pm SEM of duplicate analyses of 12 subjects. Values not followed by the same superscript letter are significantly different $(\mathrm{P}<0.05)$.

${ }^{2}$ N.D. $=$ not determined

scribed above, glycemic index was calculated with the following mean and S.E.M.: T1 Glucose drink, 100; T5=white potato, $52 \pm 14^{\mathrm{a}}$; T3 sweet potato flesh, $49 \pm 12^{\mathrm{a}}$; T2 whole sweet potato, $39 \pm 15^{\text {ab }}$; T6 white potato plus Caiapo, $30 \pm$ $8^{\mathrm{ab}}$; T4 sweet potato skin, $26 \pm 7^{\mathrm{b}}$. Treatments with glycemic indices of zero were not excluded from the data because previous data from Zakir [53] revealed the possibility of obtaining a decrease in blood glucose levels after sweet potato consumption, especially in skin fractions. The glycemic index for sweet potato skin was significantly lower than for sweet potato flesh and white potato, but was not lower than the other treatments. The GI of white potato was reduced from 52 to 30 when $4 \mathrm{~g}$ of Caiapo was added. This difference was not significant overall due to individual variability, but when one subject with a possible case of metabolic syndrome due to elevated insulin concentration was excluded, a paired $t$ test for this treatment indicated a significant difference $(P<$ 0.01). Caiapo is an extract of the skin, or cortex, of a Japanese white sweet potato. Its effectiveness in lowering blood glucose in diabetic subjects has been documented in clinical trials [54-57]. Therefore, it seems that substances that lower the blood glycemic response in the sweet potato skin may be extracted and transferred to other foods.

Insulin and C-peptide, a post-processing fragment of the insulin gene product that is not cleared from the blood by interaction with insulin receptors, were measured in this ex- periment to better understand the metabolic reaction to these carbohydrate meals. Table 2 shows the mean ( \pm S.E.M.) insulin and C-peptide responses to sweet potato and white potato samples. Insulin response to the sweet potato and white potato samples in the first hour were overall $64.7 \pm 9.4$ $\mathrm{pmol} / \mathrm{L}$ less than the glucose standard. The slopes of insulin response levels for the first and second hours were analyzed using ANOVA and Tukey's HSD test to approximate the differences in the rate of net insulin release from the first hour data and rate of insulin uptake or apparent clearance from the second hour data. There were no significant differences in mean insulin concentration by treatment over the two-hour period $(P=0.319)$. The glucose drink (T1) gave the fastest rate of insulin concentration increase among samples (110 pmol/L/hr). Sweet potato peel gave significantly less insulin release than did glucose, but the insulin release from the other treatments were not significantly different from either glucose or sweet potato peel. The significantly greater insulin release with glucose treatment (T1) than the other treatments suggests that the greater rise in blood glucose caused greater rise in insulin. In other words, for all treatments serum insulin responded to changes in serum glucose concentration, rather than some other component of the dietary treatments that could accelerate insulin release to keep blood glucose low.

\section{Glucose Response}

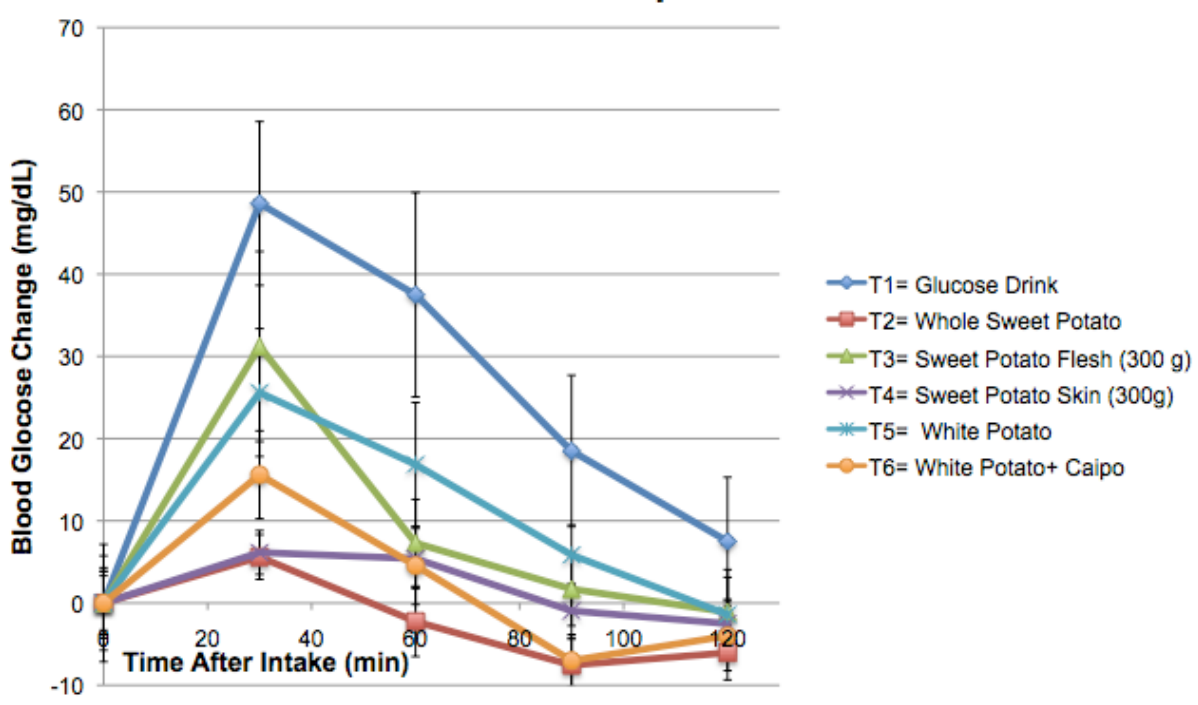

Fig. (2). Average glucose response curve relative to fasting blood glucose concentrations for treatments containing $50 \mathrm{~g}$ of carbohydrate consumed immediately after time 0 . 
Participants consuming white potato with $4 \mathrm{~g}$ of Caiapo had a mean fasting insulin level of $21.8 \pm 17.3 \mathrm{pmol} / \mathrm{L}$. Their mean post-prandial insulin level rose to $45.6 \pm 32.5 \mathrm{pmol} / \mathrm{L}$ at 60 minutes and decreased to $21.8 \pm 19.9 \mathrm{pmol} / \mathrm{L}$ at 120 minutes. A difference of $23.8 \mathrm{pmol} / \mathrm{L}$ was observed between fasting and 60 minutes. Participants consuming white potato alone had mean fasting insulin levels at $26.3 \pm 25.4 \mathrm{pmol} / \mathrm{L}$ which rose to $57.6 \pm 21.0 \mathrm{pmol} / \mathrm{L}$ after 60 minutes and declined to $26.7 \pm 21.0 \mathrm{pmol} / \mathrm{L}$ after 120 minutes. A difference of $31.3 \mathrm{pmol} / \mathrm{L}$ was observed between fasting and $60 \mathrm{~min}-$ utes.

The rate of apparent insulin clearance (concentration change from 60 to $120 \mathrm{~min}$ ) indicated no significant differences among subjects or treatments $(P=0.0530, P=0.2562$ respectively). The rank order of treatments for apparent insulin release in $0-1 \mathrm{hr}$ ( $\mathrm{T} 1$, Glucose $>\mathrm{T} 5$, Whole White Potato $>$ T6, White Potato + Caiapo > T2, Whole Sweet Potato > T3, Sweet Potato Flesh > T4, Sweet Potato Peel) was similar to the rank order of apparent insulin clearance in 1-2 hr (T1, Glucose > T5, Whole White Potato > T6, White Potato + Caiapo > T3, Sweet Potato Flesh > T2, Whole Sweet Potato $>$ T4, Sweet Potato Peel), suggesting that sweet potato peel or Caiapo did not directly alter either insulin release or insulin clearance due to receptor binding in this single-feeding experiment.

Table 2 also shows the mean C-peptide responses to the carbohydrate sources in treatments T1-T6. The slopes of Cpeptide change from $0-60 \mathrm{~min}$ demonstrate that all vegetable samples elicited lower C-peptide response levels than did the glucose drink. Due to the high inter-subject variability, none of the treatments T2-T6 was significantly different from the others although the mean values were dissimilar. The mean C-peptide increase for subjects consuming sweet potato samples was $181 \pm 44 \mathrm{pmol} / \mathrm{L}$. Conversely, white potato samples increased C-peptide $365 \mathrm{pmol} / \mathrm{L}$ from fasting-to-60minutes, while white potato plus Caiapo samples had a mean increase of $445 \mathrm{pmol} / \mathrm{L}$ during the fasting to 60 minute time interval. These mean differences could suggest that Caiapo may stimulate insulin synthesis, but no conclusion can be reached because the differences were not statistically significant.

Analysis of the decrease in C-peptide levels during the 60 to 120 minute time interval provides an apparent rate of clearance of C-peptide. There was no significant difference due to treatment in C-peptide metabolism or clearance. This result would be expected because C-peptide clearance is more likely due to plasma protein turnover and not interaction with insulin receptors. The rank order of treatments for all variables in Table $\mathbf{2}$ except C-peptide clearance were similar, with the largest values attributed to the glucose treatment and the smallest to sweet potato peel. For apparent C-peptide clearance, the mean value for T1 glucose and T4 sweet potato peel were the same.

\section{DISCUSSION}

Lipid and protein levels were unaffected by cooking methods. Total dietary fiber was higher in the skin of cooked samples; however raw sweet potato skin had dietary fiber levels similar to that of raw flesh. The amount of fiber content quantified previously [3] was 3 to 14 grams per 100 grams of sweet potato fresh weight. The amount of total dietary fiber is important because of its influence on glucose absorption, post-prandial glucose levels, and glycemic index.

High levels of total dietary fiber can cause low glycemic index levels. Leaching of sugars can occur during heat processing concentrating the fiber components of the skin [58]. The amount of lipid found in sweet potatoes has been determined to be $0.30 \pm 0.02$ grams per 100 gram raw sample [3], a value similar to the analysis of Beauregard sweet potatoes in this study. The proximate analysis was comparable to the previous results [3], although higher concentrations of lipids were found in the sweet potato skin.

Bahado-Singh, et al., [3] determined that protein levels in sweet potatoes was $2.15 \pm 0.05 \mathrm{~g}$ per 100 -g dry matter, calculated by multiplying nitrogen content by 6.25 . Similarly, this study's proximate analysis revealed protein concentrations that remained relatively constant (range $=7.4 \%$ to 9.5\%). Chang and Morris [59] found no observed statistical

Table 2. Glycemic index and the effects of consuming different fractions of Beauregard sweet potato and white potato on insulin. Values are means \pm S.E.M of 10 subjects' responses. Values within a column that have the same superscript letter are not significantly different $(\alpha=\mathbf{0 . 0 5})$

\begin{tabular}{|l|l|l|l|l|l|}
\hline Treatment & Glycemic Index & $\begin{array}{l}\text { Insulin Release } \\
(\mathbf{p m o l} / \mathbf{L} / \mathbf{h r})\end{array}$ & $\begin{array}{l}\text { Insulin Clearance } \\
(\mathbf{p m o l} / \mathbf{L} / \mathbf{h r})\end{array}$ & $\begin{array}{l}\text { C-peptide Release } \\
(\mathbf{p m o l} / \mathbf{L} / \mathbf{h r})\end{array}$ & $\begin{array}{l}\text { C-peptide Clearance } \\
(\mathbf{p m o l} / \mathbf{L} / \mathbf{h r})\end{array}$ \\
\hline \hline $\begin{array}{l}\text { 1. Glucose } \\
\text { 2. Whole Sweet } \\
\text { Potato }\end{array}$ & $39 \pm 15^{\mathrm{AB}}$ & $110 \pm 48.3^{\mathrm{A}}$ & $-52.1 \pm 17.0$ & $1114 \pm 178^{\mathrm{A}}$ & $-119 \pm 432$ \\
\hline 3. Sweet Potato Flesh & $49 \pm 12^{\mathrm{A}}$ & $20.9 \pm 8.3^{\mathrm{AB}}$ & $-17.8 \pm 9.5$ & $159 \pm 97^{\mathrm{B}}$ & $-153 \pm 89$ \\
\hline $\begin{array}{l}\text { 4. Sweet Potato Peel } \\
\text { 5. Whole White } \\
\text { Potato }\end{array}$ & $26 \pm 7^{\mathrm{B}}$ & $18.5 \pm 7.0^{\mathrm{AB}}$ & $-22.2 \pm 11.6$ & $331 \pm 66^{\mathrm{B}}$ & $-277 \pm 54$ \\
\hline $\begin{array}{l}\text { 6. White Potato }+ \\
\text { Caiapo }\end{array}$ & $30 \pm 8^{\mathrm{AB}}$ & $10.6 \pm 10.2^{\mathrm{B}}$ & $-14.3 \pm 8.7$ & $151 \pm 41^{\mathrm{B}}$ & $-119 \pm 49$ \\
\hline P & $30.9 \pm 7.8^{\mathrm{AB}}$ & $-35.0 \pm 6.9$ & $365 \pm 122^{\mathrm{B}}$ & $-266 \pm 109$ \\
\hline
\end{tabular}


differences in protein content between samples of apple, corn, oat, or soy dietary fiber sources subjected to processing treatments of autoclaving and microwaving.

Glycemic indices of zero were not omitted from the study nor were values greater than 100; negative glycemic response was given a glycemic index of zero. Individuals who had glycemic responses that created glycemic index values equal to zero indicate that breakdown of sweet potato samples could have taken longer than two hours to elicit a glucose response. Glycemic index values greater than 100 can mean that the rate at which an individual absorbed glucose from the sweet potato was faster than their response to the glucose drink standard.

The glycemic index values for raw sweet potato skin and flesh in Experiment 1 differed slightly from those in Experiment 2 , in which raw sweet potato flesh was calculated to have glycemic index of $49 \pm 12$ and skin $26 \pm 7$. Experiment 1 produced values of $28 \pm 7.3$ and $19 \pm 6.3$ respectively. The variability in glycemic index could be the result of a different year's crop, time in storage, or slightdifferences in preparation method between the two studies. Experiment 2 samples were frozen and allowed to thaw or be slightly warmed in microwaves prior to eating. Minimal cooking could have taken place, or freezing may have disrupted the cell structure. The protocol in Experiment 1 required that raw samples be kept under refrigeration $\left(4^{\circ} \mathrm{C}\right)$ and warm slowly to room temperature without being subjected to any heat. Also, different subjects were used in the two experiments to measure glycemic index. A $t$ test comparing glycemic index means from raw sweet potato skin showed statistical differences between Experiment 1 and Experiment 2. Conversely, sweet potato flesh glycemic indices were not statistically different between our two studies. The variability shown in sweet potato skin glycemic indices may be due to the microwaving done to thaw frozen samples in the second experiment. The energy from the microwave can thaw the samples of sweet potato in one minute, but some areas can become hotter than others.

The glycemic index calculated by Zakir, et al., [2] for dehydrated Beauregard sweet potato was 30 , which is not too different from the value of 40 determined in Experiment 1. Both values are lower than reported in U.S. Dietary Guidelines [50], and the values reported for cooked sweet potato [36]. The reproducible low values are beneficial for sweet potato consumers. The low glycemic index will allow for a slow rate of glucose absorption, thus maintaining low blood glucose levels. Zakir, et al., [2] suggested the possible presence of $\alpha$-amylase inhibitor protein in sweet potato skin that could cause low glycemic index values. The quantity of total dietary fiber may also have an effect on the glycemic index produced from Beauregard sweet potatoes.

The main purpose of Experiment 2 was to help elucidate such mechanisms that might be responsible for the low glycemic index in raw sweet potato and in sweet potato peel. The dietary supplement Caiapo, extracted from a white sweet potato peel, had been shown to improve glucose tolerance in several long-term clinical studies [54-56]. In the single feeding comparison of Experiment 2, we noted that Caiapo tended to lower the glycemic index of white potato, although the $22 \%$ difference was not statistically significant in this group of subjects. In contrast, Zakir, et al., [53] added
Caiapo to a glucose drink and found minimal or no effect on glycemic response.

The measurement of insulin and C-peptide changes in response to the sweetpotato in Experiment 2 was designed to determine whether these treatments increase insulin release, like diabetes drugs such as sulfonlyureas do, or increase insulin binding and uptake. The lack of significant difference between the reactions to different samples indicates that Caiapo did not significantly increase pancreatic insulin release in the first hour. The results from white potato + Caiapo are difficult to explain using the conclusion of Ludvik, et al., [40, 54] that Caiapo increases insulin efficiency, since Caiapo tended to lower the glycemic index of white potato with no prior exposure, but did not significantly change the apparent rates of insulin release or peripheral insulin clearance.

C-peptides are the protein fraction of pro-insulin that is not metabolized immediately after release because it does not react with specific receptors. Quantifying C-peptide levels post-prandially specifies how much insulin was released from the pancreas better than does the insulin concentration because insulin has a shorter half-life. The values measured for C-peptide release (427 pmol/L/hr) were 11.7 times higher than for insulin. This ratio suggests that the insulin change between 0 and $1 \mathrm{hr}$ underestimates the actual amount of insulin secretion, due to more rapid insulin turnover as it interacts with receptors on target cells. Also, the 1-hr time point in the experiment may not capture the peak insulin or Cpeptide concentration because the glucose concentration reached a peak 15-30 min after consuming carbohydrate in most individuals.

Overall, the data in Table 2 suggest that insulin and Cpeptide secretion by the pancreas responds to the elevation in blood glucose. These data do not strongly support hypotheses that raw sweet potato flesh or peel, or the Caiapo protein, lowers blood glucose by either stimulating insulin release or improving insulin sensitivity with consumption of these products in one dose.

Further research is needed to fully understand the mechanisms for the low glycemic index of raw sweet potato and the apparently lower values for skin or peel than flesh. Possible mechanisms include the dietary fiber content, starch granule structure, or other bioactivities of the protein components. One or more of these components could impact carbohydrate digestion or absorption, creating lower glycemic indices.

\section{SUMMARY \& SUGGESTIONS FOR FUTURE WORK}

Beauregard sweet potato samples had glycemic indices that were low to medium despite different methods of cooking. This may prove beneficial for diabetic patients who consume sweet potatoes. Using the glycemic index can help diabetic patients predict their daily diets to control blood glucose levels. The total dietary fiber content of sweet potatoes is enough to affect the glycemic index elicited by these roots, and we cannot rule out a bioactive effect of the protein components.

Further research quantifying the amount of maltodextrins produced from starch after various cooking procedures using HPLC can give insight to starch breakdown by cooking. 
Measuring the concentrations of the resulting sugars could help explain whether readily absorbed available carbohydrate is related to the glucose response and glycemic index [60]. Isolating the protein fractions from this or similar cultivars of sweet potato would allow for evaluation of bioactive effects.

\section{ACKNOWLEDGEMENTS}

Funding was provided by the North Carolina SweetPotato Commission and the North Carolina Agricultural Foundation.

\section{REFERENCES}

[1] Anonymous. Should you be choosing foods by their glycemic index? Tufts Univ Health NutrLett 2000; 18 (9): 4-5

[2] Zakir S, Sarwar M, Allen JC, Butt MS, Allen H. Effect of sweet potato on insulin efficiency of normal and diabetic subjects in Pakistan. Eur J Sci Res 2005; 10: 87-97.

[3] Bahado-Singh PS, Asemota HN, Morrison EYStA, Ahmad MH, Wheatley AO. Food processing methods influence the glycaemic indices of some commonly eaten West Indian carbohydrate-rich foods. Brit J Nutr 2006; 96: 476-81.

[4] Englyst HN, Cummings JH. Digestion of polysaccharides of potato in the small intestine of man. Am J Clin Nutr 1987; 45: 423-31.

[5] Thorne MJ, Thompson LU, Jenkins DJA. Factors affecting starch digestibility and the glycemic response with special references to legumes. Am J Clin Nutr 1983; 38: 481-8.

[6] Brand-Miller J, Pang E, Bramall L. Rice: a high or low glycemic index food? Proc Nutr Soc Austr 1992; 17: 226

[7] Vosloo CM .Some factors affecting the digestion of glycaemic carbohydrates and the blood glucose response. J Family Ecol Consumer Sci 2005; 33: 1-9.

[8] Bennion M, Scheule B. Introductory foods. 11th ed. New York: Prentice-Hall 2000.

[9] Asp NGL. Classification and methodology of food carbohydrates as related to nutritional effects. Am J Clin Nutri 1995; 61(suppl): 930S-7S.

[10] Cummings JH, Englyst HN. Gastrointestinal effects of food carbohydrate. Am J Clin Nutr 1995; 61(4) (suppl): 938S-45S.

[11] Colonna P, Leloup V, Buleon A. Limiting factors of starch hydrolysis. Eur J Clin Nutr 1992; 46(suppl2): S17-S32.

[12] Jing-ming L, Sen-lin Z. Scanning electron microscopy study on gelatinization of starch granules in excess water. Starch/Starke 1990; 42: 96-8.

[13] Miles MJ, Morris VJ, Orford PD, Ring SG. The roles of amylose and amylopectin in the gelation and retrogradation of starch. Carbohydrate Res 1985 ; 135: 271-81.

[14] Annison G, Topping DL. Nutritional role of resistant starch: chemical structure vs. physiological function. Annual Rev Nutr 1994; 14: 297-320.

[15] Sievert D, Czuchajowaska A, Pomeranz Y. Enzyme resistant starch. III. X-ray diffraction of autoclaved amylomaize. Cereal Chem 1991; 68: 86-91.

[16] Stephen AM, Haddad AC, Phillips SF. Passage of carbohydrate into the colon.Direct measurement in humans. Gastroenterology 1983; 85: 589-95.

[17] Englyst HN, Kingman SM, Cummings JH. Classification and measurement of nutritionally important starch fractions. Eur J Clin Nutr 1992; 46 (Supp12): S33-S50.

[18] Soh N, Brand-Miller J. The glycaemic index of potatoes: The effect of variety, cooking method and maturity. Eur J Clin Nutr 1999; 53: 249-54.

[19] Crimi S, Dimauro M, Lunetta M, Mughini L. Influence of different cooking processes on the glycemic response to potatoes in noninsulin-dependent diabetic-patients. Diabetes Nutr Metab 1995; 8: 49-53

[20] Wolever TMS, Katzman-Relle L, Jenkins AL, Vuksan V, Josee RG Jenkins DJA. Glycaemic index of 102 complex carbohydrate foods in patients with diabetes. Nutr Res 1994; 14: 651-69.

[21] Brand JC, Nicholson, PL, Thornburn AW, Truswell ASl. Food processing and the glycemic index. Amer J Clin Nutr 1985; 42: $1192-6$.
[22] Thorne MJ, Jenkins DJ, Thompson LU. Factors affecting starch digestibility and the glycemic response with special reference to legumes. Amer J Clin Nutr 1983; 38: 481-8.

[23] Collins WW, Walter Jr WM. Fresh roots for human consumption. In: Bouwkamp JC Ed. Sweet potato products: a natural resource for the tropics. Boca Raton, FL: CRC Press 1985; 205-18.

[24] Picha DH. HPLC Determinationof sugars in raw and baked sweet potatoes. J Food Sci 1985; 50: 1189-90, 1210

[25] Englyst HN, Wiggins HS, Cummings JH. Determination of the non-starch polysaccharides in plant foods by gas-liquid chromatography of constituent sugars as alditol acetates. Analyst 1982; 107: 307-18.

[26] Englyst HN, Cummings JH. Digestion of polysaccharides of potato in the small intestine of man. Am J Clin Nutr 1987; 45: 423-31.

[27] Shivaraj B, Sharma KK, Pattabiraman TN. Natural plant enzyme inhibitors: Part VII-Alpha amylase inhibitors \& amylases in plant tubers. Indian J Biochem Biophys 1979; 16: 52-5.

[28] Rekha MR, Padmaja G, Easwari ACS, Sheela MN. Cultivar differences in the alpha-amylase inhibitor activity of sweet potato and yam tubers. J Root Crops 1999; 25: 185-91.

[29] Rekha MR, Padmaja G. Alpha-amylase inhibitor changes during processing of sweet potato and taro tubers. Plant Foods Human Nutr 2002; 57: 285-94

[30] Sugiura M, Ogiso T, Takeuti K, Tamura S, Ito A. Studies on trypsin inhibitors in sweet potato I. Purification and some properties. Biochim Biophys Acta - Prot Struct 1973; 328: 407-17.

[31] Jaw KS, Chou LH, Chang SM, Duan KJ. Purification of a trypsin inhibitor from sweet potato in an aqueous two phase system. Biotechnol Lett 2007; 29: 137-40.

[32] Hou W, Lin Y. Polyamine-bound trypsin inhibitors in sweet potato (Ipomoea batatas [L.] Lam cv. Tainong 57) storage roots, sprouted roots and sprouts. Plant Sci 1997; 126: 11-9.

[33] Obidairo TK, Akpochafo OM. Isolation and characterization of some proteolytic enzyme inhibitors in sweet potato (Ipomoea batatas). Enzyme Microbiol Technol 1984; 6: 132-4.

[34] Kiran KS, Padmaja G. Inactivation of trypsin inhibitors in sweet potato and taro tubers during processing Plant Foods Hum Nutr 2003; 58: 153-63.

[35] Zhang Z, Corke H. Trypsin inhibitor activity in vegetative tissue of sweet potato plants and its response to heat treatment. J Sci Food Agric 2001; 81: 1358-63.

[36] Atkinson FS, Foster-Powell K, Brand-Miller JC. International tables of glycemic index and glycemic load values: 2008. Diabetes Care 2008; 31: 2281-3.

[37] Takahata Y, Noda T, Nagata T. Varietal diversity of free sugar composition in storage root of sweet potato. Jpn J Breed 1992; 42 : 515-21.

[38] Walter WM, Purcell AE, Nelson AM. Effects of amylolytic enzymes on "moistness" and carbohydrate changes of baked sweet potato cultivars. J Food Sci 1975; 40: 793-6.

[39] Corbitt AD. Characterization of the glycemic index of raw and thermally processed sweet potatoes (Ipomea batatas L.). M.S. Thesis. Raleigh NC: North Carolina State University 2007 [Cited 2011 Apr 24]. Available from: http: //repository.lib.ncsu.edu/ir/ handle/1840.16/786.

[40] Ludvik B, Mahdjoobian K, Waldhaeusi W, et al. The effect of Impomea batatas (Caiapo) on glucose metabolism and serum cholesterol in patients with type II diabetes. Diabetes Care 2002; 25: 239-40.

[41] Zakir S, Sarwar M, Allen J, Khan MN, Butt MS. Variation in physio-chemical characteristics of somecultivars of sweet potato. Pak J Bot 2006; 38: 283-91.

[42] Truong VD, Biermann CJ, Marlett JA. Simple sugars, oligosaccharides and starch concentrations in raw and cooked sweetpotato. J Agric Food Chem 1986; 34: 421-5.

[43] Nishimune T, Yakushiji T, Sumimoto T, et al. Glycemic response and fiber content of some foods. Am J Clin Nutr 1991; 54: 414-9.

[44] Truout DL, Behall KM, Osilesi O. Prediction of glycemic index for starchy foods. Am J Clin Nutr 1993; 58: 873-8.

[45] North Carolina Sweet Potato Commission. [cited 2011 Apr 22] http: //www.ncsweetpotatoes.com/

[46] The Association of Official Analytical Chemists. Official methods of analysis. 15th Edition. Arlington, USA: AOAC 1990

[47] Ramdath DD, Isaacs RLC, Teelucksing S, Wolever TMS. Glycaemic index of selected staples commonly eaten in the Caribbean and the effects of boiling v. crushing. Br J Nutr 2004; 91: 971-7. 
[48] Wallace AJ, Willis JA, Monro JA, Frampton CM, Hedderley DI, Scott RS. No difference between venous and capillary blood sampling and the MiniMed continuous glucose monitoring system for determining the blood glucose response to food. Nutr Res 2006; 26: 403-8.

[49] Wolever TMS, Jenkins DJA, Jenkins AL, Josse RG. The glycemic index: methodology and clinical implications. Am J Clin Nutr 1991; 54: 846-54.

[50] U.S. Department of Agriculture, U.S. Department of Health and Human Services, Dietary Guidelines for Americans 2010 [Cited 2011 Apr 24]. Available from: http: //www.dietaryguidelines. gov/

[51] Lanza E, Jones D, Block G, Kessler L. Dietary fiber intake in the US population. Amer J Clin Nutr 1987; 46: 790-7.

[52] Southgate DAT. Determination of carbohydrates in foods II. Unavailable carbohydrates. J Sci Food Agric 1969; 20: 331-5.

[53] Zakir S, Sarwar M, Allen J, Butt MS, McClelland J. Impact of sweet potatoes cultivars on postprandial blood glucose level in normal and diabetics subjects: Empirical test of hypotheses on Pakistani data. Eur J Sci Res 2005; 11: 171-84.

[54] Ludvik B, Waldhausl W, Prager R, Kautzky-WillerA, Pacini G. Mode of action of Ipomoea batatas (Caiapo) in type 2 diabetic patients. Metabolism 2003; 5: 875-80.
[55] Ludvik B, Neuffer B, Pacini G. Efficacy of Ipomoea batatas (Caiapo) on diabetes control in type 2 diabetic subjects treated with diet. Diabetes Care 2004; 27: 436-40.

[56] Ludvik B, Hanefeld M, Pacini G. Improved metabolic control by Ipomoea batatas (Caiapo) is associated with increased adiponectin and decreased fibrinogen levels in type 2 diabetic subjects. Diabetes Obes Metab 2008; 10: 586-92.

[57] Kusano S, Tamasu S, Nakatsugawa S. Effects of the white-skinned sweet potato (Ipomoea batatas L.) on the expression of adipocytokine in adipose tissue of genetic type 2 diabetic mice. Food Sci Technol Res 2005; 11: 369-72.

[58] Reddy N, Sistrunk W. Effect of cultivar, size, storage, and cooking method on carbohydrates and some nutrients of sweet potatoes. J Food Sci 1980; 45: 682-84.

[59] Chang MC, Morris WC. Effect of heat treatments on chemical analysis of dietary fiber. J Food Science 1990; 55: 1647-75.

[60] Lewthwaite SL, Sutton KH, Triggs CM. Free sugar composition of sweet potato cultivars after storage. New Zealand J Crop Hort Sci 1997; 25: 33-41.

(C) Allen et al.; Licensee Bentham Open

This is an open access article licensed under the terms of the Creative Commons Attribution Non-Commercial License (http://creativecommons.org/licenses/by-nc/3.0/) which permits unrestricted, non-commercial use, distribution and reproduction in any medium, provided the work is properly cited. 